\title{
Az ellenoldali csípőtáji törésig eltelt időt befolyásoló prognosztikai tényezők vizsgálata
}

\author{
Juhász Krisztina dr. ${ }^{1}$ - Boncz Imre dr. ${ }^{2,3}$ \\ Kanizsai Péter dr. ${ }^{4}$. Sebestyén Andor dr. ${ }^{2,3}$ \\ ${ }^{1}$ Baranya Megyei Kormányhivatal, Népegészségügyi Osztály, Pécs \\ Pécsi Tudományegyetem, 2általános Orvostudományi Kar, Klinikai Központ, \\ ${ }^{3}$ Egészségtudományi Kar, Egészségbiztosítási Intézet, Pécs \\ ${ }^{4}$ Semmelweis Egyetem, Orvostudományi Kar, Klinikai Központ, Sürgősségi Betegellátó Osztály, Budapest
}

Bevezetés: Az ellenoldali csípőtáji törések előfordulását számos nemzetközi tanulmány vizsgálta, azonban az ellenoldali törésig eltelt időre vonatkozóan nem rendelkezünk adattal.

Célkitüzés: A tanulmány célja volt meghatározni az egyes prognosztikai faktoroknak az ellenoldali csípőtáji törésig eltelt időre kifejtett hatását, illetve a combnyaktörést követő ellenoldali csípőtáji törések előfordulását.

Módszer: A vizsgálatban 60 éves, illetve idősebb - 2000-ben combnyaktörés miatt operált - betegek kerültek elemzésre, akik 2008. december 31-ig ellenoldali csípőtáji törést szenvedtek. A prognosztikai tényezők közül vizsgáltuk a nemnek, a kornak, a kísérő betegség jelenlétének, a combnyaktörés és a primer mútét típusának, a lakhelynek, illetve a primer ellátás szintjének a szerepét, melyeket egyutas varianciaanalízissel értékeltünk az ellenoldali csípőtáji törésig eltelt idő tekintetében.

Eredmények: A kritériumoknak 312 beteg felelt meg. A combnyaktörést követő ellenoldali csípőtáji törések évenkénti előfordulása 1,5 és 2,1\% között változott, a kumulatív incidencia 8,24\% volt az utánkövetési időben. Az ellenoldali csípő́táji törésig átlagosan 1159,8 nap telt el. Az ellenoldali csípőtáji törések előfordulása egyik évben sem mutatott szignifikáns eltérést egymástól. Az idősebb combnyaktörött betegek esetében szignifikánsan rövidebb idő $(\mathrm{p}=0,010)$ telt el az ellenoldali csípótáji törésig.

Következtetések: A 60 év feletti combnyaktörötteknél az ellenoldali csípőtáji törések évenkénti előfordulása szignifikáns különbséget nem mutat. Az idősebb korcsoportok esetében az ellenoldali csípőtáji törésig eltelt rövidebb idő felhívja a figyelmet az ellenoldali csípótáji törések prevenciós stratégiájának fontosságára.

Orv Hetil. 2018; 159(38): 1543-1547.

Kulcsszavak: combnyaktörés, ellenoldali csípőtáji törés, incidencia, eltelt idő, prognosztikai tényezők

\section{Analysis of the prognostic factors influencing the time elapsing until the contralateral hip fracture}

Introduction: Although several national studies reported on the risk factors for contralateral hip fracture, there are no data about the prognostic factors of the time until contralateral hip fractures.

Aim: The aim of the study was to analyse the impact of different prognostic factors on the time until the development of contralateral fracture and to determine the incidence of contralateral hip fractures after femoral neck fractures.

Method: Patients aged 60 years and over with contralateral hip fracture between 01 Jan 2000 and 31 Dec 2008 were identified among those who suffered their femoral neck fracture in Hungary in 2000. Risk factors as age, sex, comorbidities, type of fracture and surgery, place of living and hospitals providing treatment for primary fracture were analysed by one way ANOVA focusing on the time until the development of contralateral hip fracture.

Results: 312 patients met the inclusion criteria. The incidence of contralateral hip fracture after femoral neck fracture ranged between $1.5 \%$ and $2.1 \%$, the cumulative incidence was $8.24 \%$. The mean time until the development of contralateral hip fracture was 1159.8 days. The incidence of contralateral hip fracture showed no significant deviation. Significantly shorter time $(\mathrm{p}=0.010)$ was detected until the contralateral hip fracture in older patients with femoral neck fracture. 
Conclusions: The yearly incidence of contralateral hip fracture showed no significant difference by patients with femoral neck fracture over 60 years. The shorter time until the contralateral hip fracture by the older age groups highlights the need of elaboration of prevention strategies.

Keywords: femoral neck fracture, contralateral hip fracture, incidence, elapsed time, prognostic factors

Juhász K, Boncz I, Kanizsai P, Sebestyén A. [Analysis of the prognostic factors influencing the time elapsing until the contralateral hip fracture]. Orv Hetil. 2018; 159(38): 1543-1547.

(Beérkezett: 2018. április 29.; elfogadva: 2018. május 24.)

\section{Rövidítések}

ANOVA $=($ analysis of variance $)$ varianciaanalízis; $\mathrm{BNO}=\mathrm{Be}-$ tegségek Nemzetközi Osztályozása

A csípőtáji törés az időskori törések egyik leggyakoribb és legsúlyosabb formája, melynek incidenciája földrajzilag széles határok között változik, a leggyakoribb ÉszakEurópában (Norvégiában nőknél 920/100 000, férfiaknál 399,3/100 000) és az Amerikai Egyesült Államokban, míg a legritkább Afrikában (Kamerunban nőknél 57,1/100 000, férfiaknál 43,7/100 000) [1-3].

Primer csípőtáji törést szenvedett betegek további csípőtáji törések tekintetében kétszeres kockázatnak vannak kitéve az átlagpopulációhoz képest [4]. Irodalmi adatok szerint a második csípőtáji törések incidenciája 2-20\% között változik [5-7], melyekhez a szövődmények gyakoribb előfordulása, rosszabb funkcionális status és magasabb mortalitás társul $[8,9]$.

A második csípőtáji törések kialakulását befolyásoló faktorokat számos nemzetközi tanulmány [10-12] elemezte. Lehetséges kockázati tényezői között vizsgálták a következők szerepét: kor, nem, testsúly, a trauma mechanizmusa, a törés lokalizációja, kísérő betegségek, a mütét típusa, vérvesztés, pre- és posztoperatív hemoglobin és hematokrit, posztoperatív komplikációk, az osteoporosis súlyossága (Singh-index), kórházban töltött idő, valamint testtömegindex $[13,14]$. Korábbi tanulmányunkban magyarországi adatok elemzésével az ellenoldali csípótáji törések rizikófaktoraiként a magasabb életkort, a városi lakhelyet és az arthroplasticai mútéti típust igazoltuk [15].

Az irodalomban nem találtunk adatot az ellenoldali csípőtáji törésig eltelt idő tartamát befolyásoló tényezőkről. Ugyanakkor a csípőtáji törések orvosszakmai és egészségpolitikai jelentősége, társadalmi terhe kiemelkedő [16-25].

Jelen tanulmányunk célja meghatározni, hogy az egyes rizikófaktorok hogyan befolyásolják az időskori combnyaktörést követő ellenoldali csípótáji törésig eltelt idő intervallumát.

\section{Módszer}

Vizsgálatunk során a Nemzeti Egészségbiztosítási Alapkezelő adatbázisából származó combnyaktörött betegek adatait dolgoztuk fel. A vizsgálatba olyan 60 éves, illetve idősebb, 2000-ben fekvőbeteg-ellátó intézményben monotrauma miatt combnyaktöréssel (BNO-kód: S7200) operált betegek kerültek, akik 2000. január 1. és 2008. december 31. között ellenoldali csípótáji törést szenvedtek. Az adatok validálása és kiegészítése országos szinten az ellátóintézmények segítségével történt.

A combnyaktörést követően kialakult ellenoldali csípőtáji törések incidenciáját (\%) és megoszlását vizsgáltuk évenként és kumuláltan.

Az ellenoldali csípőtáji törésig eltelt időt a különböző prognosztikai tényezők ismeretében elemeztük. Vizsgáltuk a betegek nemét, életkorát (korcsoportos bontásban: 60-69, 70-79, 80-89, 90 év feletti), kísérő betegségét (van/nincs), a combnyaktörés típusát (intracapsularis nem diszlokált [Garden I-II.], intracapsularis diszlokált [Garden III-IV.] és extracapsularis), a primer mütét típusát (osteosynthesis, arthroplastica), a páciensek lakhelyét (község, város, megyei jogú város, fővárosi kerület) és a törésellátás szintjét (városi, megyei, fơvárosi, egyetemi és országos intézet) a combnyaktörés ellátásakor. Nem jelen tanulmányunk keretei között kerül értékelésre a combnyaktörést követő osteoporosisterápia és a mozgásszervi rehabilitációs kezelések, valamint az ellenoldali csípőtáji törésig eltelt idő összefüggéseinek kérdése.

$\mathrm{Az}$ adatok statisztikai feldolgozását az SPSS 19.0 programmal végeztük. A mintán leíró statisztikai elemzést végeztünk. A vizsgált csoportoknak az ellenoldali csípőtáji törésig eltelt időre vonatkozó értékeit egyutas varianciaanalízissel (ANOVA) hasonlítottuk össze. Khinégyzet-próbával vizsgáltuk, hogy van-e szignifikáns különbség a combnyaktörést követő ellenoldali csípőtáji törések évenkénti előfordulása között. Szignifikanciaszintnek a $\mathrm{p} \leq 0,05$ értéket tekintettük.

\section{Eredmények}

Vizsgálatunk alapját 3783 fó 60 éves, illetve idősebb 2000-ben combnyaktörés miatt operált - beteg képezte, akik közül 2008. december 31-ig 312 beteg $(8,24 \%)$ szenvedett ellenoldali csípőtáji törést és került elemzésre. 2689 (71,08\%) beteg meghalt, illetve 782 (20,68\%) fó túlélte az utánkövetési periódust ellenoldali csípőtáji törés nélkül. 


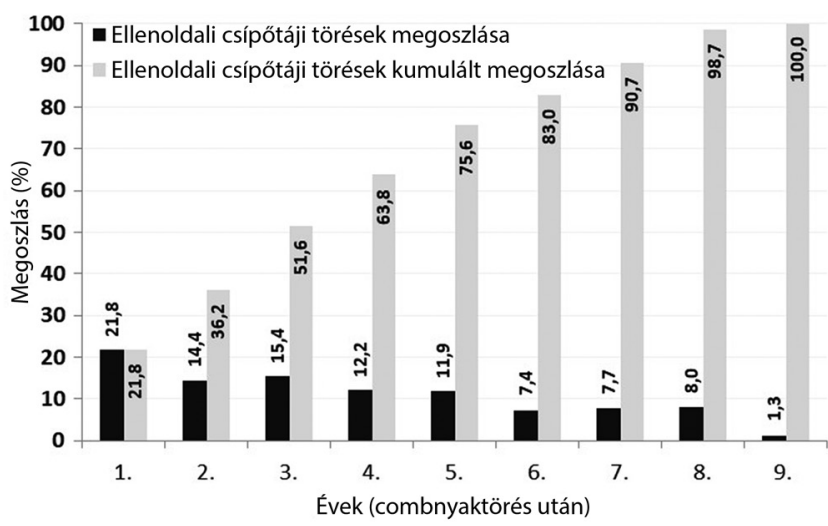

1. ábra $\quad$ A combnyaktörést követő ellenoldali csípőtáji törések évenkénti megoszlása és kumulatív megoszlása az utánkövetési időben

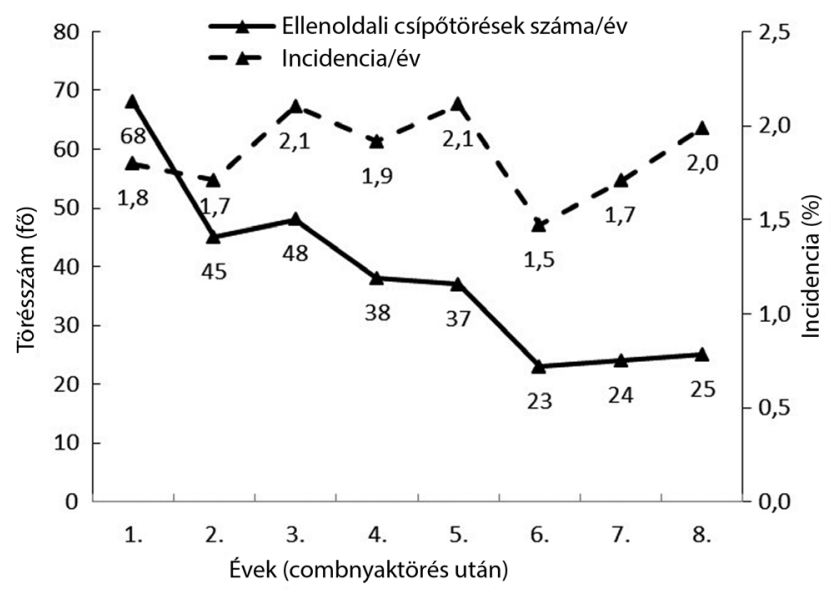

2. ábra

Az ellenoldali csípőtáji törések száma és incidenciája (\%) évenként a combnyaktörést követően (a 9. tört év 4 esete nem került ábrázolásra torzító hatása miatt)

Az ellenoldali csípőtáji törést szenvedett betegek átlagéletkora a combnyaktöréskor 77,6 év, az ellenoldali csípőtáji töréskor 80,9 év volt. Az ellenoldali csípőtáji törésig eltelt idő 2 és 3202 nap között változott. Átlagosan 1159,8 nap telt el az ellenoldali törésig, a medián érték 1045,50 nap volt.

Az ellenoldali csípótáji törések száma a combnyaktöréseket követő első évben 68 fö, a második és a harmadik évben 45 és 48 fó, míg a nyolcadik évben 25 fö volt. Az évenkénti incidencia 1,5\% és 2,1\% között változott. Nem mutatkozott statisztikailag szignifikáns különbség a vizsgált években előforduló ellenoldali csípőtáji törések gyakorisága között. Az ellenoldali csípőtáji törések 21,8\%-a az első évben, 36,2\%-két év alatt, 75,6\%-a öt éven belül következett be (1. és 2. ábra). A kétéves kumulatív incidencia 2,99\%, a hároméves 4,26\%, az ötéves 6,24\%, a nyolcéves $8,14 \%$ volt.

Az ellenoldali csípőtáji törésig eltelt idő az idősebb korcsoportokban szignifikánsan alacsonyabbnak ( $\mathrm{p}=$ $0,010)$ bizonyult a fiatalabbakhoz képest. Nem mutatott szignifikáns eltérést a nem $(\mathrm{p}=0,414)$, a kísérő betegség jelenléte $(\mathrm{p}=0,104)$, a törés típusa $(\mathrm{p}=0,627)$, a mútét típusa $(\mathrm{p}=0,070)$, a lakhely típusa $(\mathrm{p}=0,566)$, valamint az ellátás progresszivitási szintje $(\mathrm{p}=0,398)$ az ellenoldali törésig eltelt idő tekintetében (1. táblázat).

\section{Megbeszélés}

Tanulmányunkban a combnyaktöréseket követő ellenoldali csípőtáji törések előfordulását, illetve a törésig eltelt idő kockázati tényezőit vizsgáltuk. Az irodalomban a combnyaktörést követő ellenoldali csípőtáji törésig eltelt időre és előfordulásra vonatkozóan a különböző módszertanok miatt kevésbé összehasonlítható adatok állnak rendelkezésre.

Vizsgálatunk szerint az ellenoldali csípőtáji törések 21,8\%-a az első évben, 36,2\%-a két év alatt, 75,6\%-a öt éven belül következett be a közel nyolcéves utánkövetési periódusban. Von Friesendorff és mtsai adatai alapján 799 , primer csípőtáji törést szenvedett nőt 22 évig követve a második csípőtáji törések 27\%-a 2 éven, $73 \%$-a 5 éven belül történt meg [26]. Ryg és mtsai a második csípőtáji törések kumulatív incidenciáját 25 évig 169145 betegen végzett tanulmányukban az első év után 9\%nak, 5 év után 20\%-nak találták [27].

Jelen elemzésünkben átlagosan 1159,8 nap (38,6 hónap) telt el az ellenoldali törésig, a medián érték 1045,5 nap (34,85 hónap) volt. Lee és mtsai 2546 , primer csípőtáji törött beteget 10 évig vizsgálva a következő csípőtáji törésig eltelt átlagos időt 30,2 hónapnak találták [28]. Chang és mtsai 22,7 hónapos átlagos időtartamról számoltak be a primer és az ellenoldali csípőtáji törés között. Vizsgálatuk szerint 1093, csípótáji törött beteget 4 évig vizsgálva az ellenoldali csípőtáji törések 38,8\%-a 1 éven belül, 66\%-a két éven belül következett be [29]. Berry és mtsai 481, primer csípőtáji törött beteget 51 évig követve a primer és a második csípőtáji törés között eltelt idő medián értékére vonatkozóan 4,2 évről számoltak be, ahol a második csípőtáji törések előfordulása az első évben 2,5\%-nak, öt éven belül 8,2\%-nak bizonyult [30]. Lönnroos és mtsai 501, primer csípőtáji törött betegnél kialakult második csípőtáji töréseket öt évig vizsgálva a medián követési időt 25,5 hónapnak, a kumulatív incidenciát az első évben 5,08\%-nak találták [31].

Az ellenoldali csípőtáji törésig eltelt idő nagyságát befolyásoló faktorokra vonatkozóan a nemzetközi szakirodalomban nem találtunk adatot. A vizsgált kockázati tényezők és az ellenoldali csípőtáji törésig eltelt idő tekintetében megállapítottuk, hogy a combnyaktörést követően elszenvedett ellenoldali csípőtáji törésig rövidebb idő telik el az idősebb korcsoportok esetében, ami magyarázható az idősebb korosztály rosszabb általános állapotával, az esések gyakoribb előfordulásával, valamint az osteoporosis nagyobb térhódításával $[32,33]$. Nem mutatott szignifikáns összefüggést a nem, a kísérő betegségek jelenléte, a combnyaktörés típusa, a mútét típusa, a lakhely és a primer ellátás szintje az ellenoldali csípőtáji törésig eltelt idő tekintetében. 
1. táblázat $\mid$ A combnyaktörést követő ellenoldali csípőtáji törések száma és megoszlása (I. oszlop), az ellenoldali csípótáji törésig eltelt idő (II. oszlop), valamint az ANOVA-elemzés értéke (III. oszlop) a prognosztikai tényező́k függvényében

\begin{tabular}{|c|c|c|c|c|}
\hline \multirow[t]{2}{*}{ Prognosztikai tényezók } & \multicolumn{2}{|c|}{ I. Ellenoldali csípőtáji törések } & \multirow{2}{*}{$\begin{array}{c}\begin{array}{c}\text { II. Az ellenoldali csípőtáji törésig } \\
\text { eltelt idő [nap] }\end{array} \\
\text { Átlag [nap] }\end{array}$} & \multirow{2}{*}{$\begin{array}{c}\text { III. } \\
\text { p-érték }\end{array}$} \\
\hline & Esetszám & Megoszlás [\%] & & \\
\hline \multicolumn{5}{|l|}{ Nem } \\
\hline Nő & 263 & 84,3 & 1141,82 & \multirow{2}{*}{0,414} \\
\hline Férfi & 49 & 15,7 & 1256,06 & \\
\hline \multicolumn{5}{|l|}{ Korcsoport } \\
\hline 60-69 év & 53 & 18 & 1416,62 & \multirow{4}{*}{0,010} \\
\hline 70-79 év & 148 & 47 & 1207,43 & \\
\hline 80-89 év & 97 & 31 & 1015,62 & \\
\hline 90 év- & 14 & 4 & 682,14 & \\
\hline \multicolumn{5}{|l|}{ Kísérő betegség } \\
\hline Van & 274 & 87,8 & 1128,98 & \multirow{2}{*}{0,104} \\
\hline Nincs & 38 & 12,2 & 1381,71 & \\
\hline \multicolumn{5}{|l|}{ A combnyaktörés típusa } \\
\hline Nem diszlokált intracapsularis & 67 & 21,5 & 1166,19 & \multirow{3}{*}{0,627} \\
\hline Diszlokált intracapsularis & 219 & 70,2 & 1177,08 & \\
\hline Extracapsularis & 26 & 8,3 & 997,27 & \\
\hline \multicolumn{5}{|l|}{ A primer műtét típusa } \\
\hline Osteosynthesis & 251 & 80,4 & 1205,17 & \multirow{2}{*}{0,070} \\
\hline Arthroplastica & 61 & 19,6 & 972,90 & \\
\hline \multicolumn{5}{|l|}{ Lakhely } \\
\hline Község & 76 & 24,4 & 1241,22 & \multirow{5}{*}{0,566} \\
\hline Város & 78 & 25 & 1132 & \\
\hline Megyei jogú város & 58 & 18,6 & 1179,47 & \\
\hline Fővárosi kerület & 84 & 26,9 & 1054,02 & \\
\hline Nincs adat & 16 & 5,1 & 1391,81 & \\
\hline \multicolumn{5}{|l|}{ A primer ellátás szintje } \\
\hline Város & 104 & 33,3 & 1256,34 & \multirow{4}{*}{0,398} \\
\hline Megye & 88 & 28,2 & 1184,15 & \\
\hline Főváros & 72 & 23,1 & 1031,78 & \\
\hline Országos intézet és egyetemek & 48 & 15,4 & 1097,77 & \\
\hline
\end{tabular}

ANOVA = varianciaanalízis

Tanulmányunk limitációja, hogy az elsőnek vélt combnyaktörést megelőző időszakban előforduló esetleges csípőtáji törésekről nem áll rendelkezésre információ, így az ellenoldali csípőtáji törések száma és előfordulása feltehetôen nagyobb a tanulmányban számolt értékeknél.

\section{Következtetés}

A combnyaktörést követő ellenoldali csípőtáji törések évenkénti előfordulása nem mutatott szignifikáns különbséget. Az ellenoldali csípótáji törések többsége a combnyaktörést követő öt éven belül következett be. Az idősebb korcsoportok esetében az ellenoldali csípőtáji törésig eltelt rövidebb idő felhívja a figyelmet a törésmegelőző prevenciós stratégiák mielőbbi kidolgozásának szükségességére. Addig is a csípőtáji töréseket követően az osteoporoticus betegek azonosítása és terápiája javasolt az alapellátó és szakellátó rendszer integrált együttmúködésével a további törések megelőzése érdekében.

Anyagi támogatás: A szerzők a közlemény megírásáért anyagi támogatásban nem részesültek.

Szerzői munkamegosztás: J. K.: Irodalomkutatás, az információk szintetizálása, szövegezés. B. I., K. P., S. A.: 
Szakmai lektorálás, a kézirat szövegezésének véglegesítése. A cikk végleges változatát valamennyi szerző elolvasta és jóváhagyta.

Érdekeltségek: A szerzőknek nincsenek érdekeltségeik.

\section{Irodalom}

[1] Dhanwal DK, Dennison EM, Harvey NC, et al. Epidemiology of hip fracture: Worldwide geographic variation. Indian J Orthop. 2011; 45: 15-22.

[2] Leslie WD, O'Donnell S, Lagacé C, et al. Population-based Canadian hip fracture rates with international comparisons. Osteoporos Int. 2010; 21: 1317-1322.

[3] Zebaze RM, Seeman E. Epidemiology of hip and wrist fractures in Cameroon, Africa. Osteoporos Int. 2003; 14: 301-305.

[4] Klotzbuecher CM, Ross PD, Landsman PB, et al. Patients with prior fractures have an increased risk of future fractures: a summary of the literature and statistical synthesis. J Bone Miner Res. 2000; 15: 721-739.

[5] Kaper BP, Mayor MB. Incidence of bilateral proximal femoral fractures in a tertiary care center. Orthopedics $2001 ; 24$ : 571574.

[6] Berry SD, Samelson EJ, Hannan MT, et al. Second hip fracture in older men and women: the Framingham Study. Arch Intern Med. 2007; 167: 1971-1976.

[7] Lau JC, Ho KW, Sadiq S. Patient characteristics and risk of subsequent contralateral hip fracture after surgical management of first fracture. Injury 2014; 45: 1620-1623.

[8] Bliuc D, Nguyen ND, Milch VE, et al. Mortality risk associated with low-trauma osteoporotic fracture and subsequent fracture in men and women. JAMA 2009; 301: 513-521.

[9] Holt G, Smith R, Duncan K, et al. Outcome after sequential hip fracture in the elderly. J Bone Joint Surg Am. 2012; 94: 18011808.

[10] Angthong C, Suntharapa T, Harnroongroj T. Major risk factors for the second contralateral hip fracture in the elderly. Acta Orthop Traumatol Turc. 2009; 43: 193-198.

[11] Yamanashi A, Yamazaki K, Kanamori M, et al. Assessment of risk factors for second hip fractures in Japanese elderly. Osteoporos Int. 2005 ; 16: 1239-1246.

[12] Egan M, Jaglal S, Byrne K, et al. Factors associated with a second hip fracture: a systematic review. Clin Rehabil. 2008; 22: 272282.

[13] De Laet C, Kanis JA, Odén A, et al. Body mass index as a predictor of fracture risk: a meta-analysis. Osteoporos Int. 2005; 16 : $1330-1338$

[14] Kok LM, van der Steenhoven TJ, Nelissen RG. A retrospective analysis of bilateral fractures over sixteen years: localisation and variation in treatment of second hip fractures. Int Orthop. 2011; 35: 1545-1551.

[15] Juhász K, Boncz I, Patczai B, et al. Risk factors for contralateral hip fractures following femoral neck fractures in elderly: analysis of the Hungarian nationwide health insurance database. Eklem Hastalik Cerrahisi 2016; 27: 146-152.

[16] Sebestyén A, Mester S, Vokó Z, et al. Wintertime surgery increases the risk of conversion to hip arthroplasty after internal fixation of femoral neck fracture. Osteoporos Int. 2015; 26: 1109-1117.

[17] Sebestyén A, Tóth F, Sándor J, et al. Correlation between risk factors and subsequent surgical management following internal fixation of intracapsular femoral neck fractures in patients under the age of 60 years. Eur J Trauma Emerg Surg. 2011; 37: 503510 .
[18] Sebestyén A, Boncz I, Sándor J, et al. Effect of surgical delay on early mortality in patients with femoral neck fracture. Int Orthop. 2008 ; 32: 375-379.

[19] Sebestyén A, Boncz I, Dózsa Cs, et al. Cost analysis of peritrochanteric fractures according to types of surgical treatment and progressive care from the viewpoint of financial providers. [Trochantertáji törések ellátásának költségvizsgálata a mútéti eljárások és a progresszív ellátási szintek szerint finanszírozói szemszögből.] Orv Hetil. 2004; 145: 1115-1121. [Hungarian]

[20] Endrei D, Molics B, Ágoston I. Multicriteria decision analysis in the reimbursement of new medical technologies: real-world experiences from Hungary. Value Health 2014; 17: 487-489.

[21] Boncz I, Nagy J, Sebestyén A, et al. Financing of health care services in Hungary. Eur J Health Econ. 2004; 5: 252-258.

[22] Sebestyén A, Boncz I, Nyárády J. Analysis of health insurance costs in cases of patients under 60 years old with medial femoral neck fracture treated primarily with screw fixation or hip replacement. [Az egészségbiztosítási költségek elemzése az elsődlegesen csavaros osteosynthesissel, illetve protézisbeültetéssel kezelt, 60 évesnél fiatalabb mediális combnyaktörést szenvedett betegek eseteiben.] Orv Hetil. 2006; 147: 1129-1135. [Hungarian]

[23] Flóris I, Belicza É. Analysis of hip fracture care in Hungary between 2004-2009. [A csípőtáji törések hazai ellátásának elemzése a 2004-2009 közötti időszakban.] Orv Hetil. 2016; 157: 16421648. [Hungarian]

[24] Juhász K, Turchányi B, Mintál T, et al. Multidisciplinary approach of hip fractures based on Hungarian data. [Csípőtáji törések multidiszciplináris aspektusai magyarországi adatok alapján.] Orv Hetil. 2016; 157: 1469-1475. [Hungarian]

[25] Péntek M, Gulácsi L, Tóth E, et al. Ten-year fracture risk by FRAX $^{(\circledast)}$ of women with osteoporosis attending osteoporosis care in Hungary. [A szakellátásban megjelenő osteoporosisos nők 10 éves csonttöréskockázata a FRAX ${ }^{\circledR}$ alapján.] Orv Hetil. 2016; 157: 146-153. [Hungarian]

[26] von Friesendorff M, Besjakov J, Akesson K. Long-term survival and fracture risk after hip fracture: a 22 -year follow-up in women. J Bone Miner Res. 2008; 23: 1832-1841.

[27] Ryg J, Rejnmark L, Overgaard S, et al. Hip fracture patients at risk of second hip fracture: a nationwide population-based cohort study of 169,145 cases during 1977-2001. J Bone Miner Res. 2009; 24: 1299-1307.

[28] Lee KH, Kim JY, Yim SJ, et al. Incidence and risk factors of subsequent hip fractures in Korea: multicenter study. J Korean Med Sci. 2014; 29: 992-994.

[29] Chang JD, Yoo JH, Reddy P, et al. Risk factors for contra-lateral hip fracture in elderly patients with previous hip fracture. Injury 2013; 44: 1930-1933.

[30] Berry SD, Samelson EJ, Hannan MT, et al. Second hip fracture in older men and women: the Framingham Study. Arch Intern Med. 2007; 167: 1971-1976.

[31] Lönnroos E, Kautiainen H, Karppi P, et al. Incidence of second hip fractures. A population-based study. Osteoporos Int. 2007; 18: 1279-1285.

[32] Stenvall M, Olofsson B, Lundström M, et al. Inpatient falls and injuries in older patients treated for femoral neck fracture. Arch Gerontol Geriatr. 2006; 43: 389-399.

[33] Yeh HF, Shao JH, Li CL, et al. Predictors of postoperative falls in the first and second postoperative years among older hip fracture patients. J Clin Nurs. 2017; 26: 3710-3723.

(Juhász Krisztina dr., Pécs, Szabadság út 7., 7623 e-mail: krisztina.juhasz01@gmail.com)

A cikk a Creative Commons Attribution-NonCommercial 4.0 International License (https://creativecommons.org/licenses/by-nc/4.0) feltételei szerint publikált Open Access közlemény, melynek szellemében a cikk nem kereskedelmi célból bármilyen médiumban szabadon felhasználható, megosztható és újraközölhető, feltéve, hogy az eredeti szerzỏ és a közlés helye, illetve a CC License linkje és az esetlegesen végrehajtott módositások feltüntetésre kerülnek. 